\title{
EXCURSION TO CHARNWOOD FOREST.
}

\section{MONDAY AND TUESDAY, MAY 21ST AND 22ND, 1888.}

Directors: Rev. E. HILL, M.A., F.G.S., and J. D. PAUL, F.G.S.

(Report by Mr. PAणr.)

After a lapse of thirteen years the Association decided to revisit Charnwood Forest for its Whitsuntide Excursion. The programme was arranged with the idea of showing to the Members the advances which had been made since their last visit in the solution of the geological problems suggested by the district. The first step in working out its geology was made by Sedgwick in 1833 , when he correctly laid down the position of the anticlinal, and the Rev. W. H. Coleman* subsequently did a great deal of excellent field-work. Beete Jukes also, who was employed for a year or two in the neighbourhood, published in 1842 his Memoir, containing the earliest geological map and survey of the Forest. His explanation of the geology of the district was the result of much accurate observation, combined with a thorongh knowledge of the science as it was then generally understood; but it was vitiated by the mistake which led him to set down as igneous, the porphyries whose outcrops occupy such a large area to the north-west. This error remained uncorrected till Messrs. Hill and Bonney read their first paper before the Geological Society in 1877, an the "Pre-Carboniferous Rocks of Charnwood Forest." The advances which had been made in petrology and the use of the microscope in the examination of rocks enabled them to demonstrate that the Forest contained an important series of altered volcanic rocks, and to distinguish these from the intrusive igneous syenites, granites, and basalts.

The first day's Excursion of the Association was to the southern end of the anticlinal at Holgate Hill, in Bradgate Park. The banded slates forming the face of the cliff at this locality were carefully examined, and the stripe, showing a dip to south-west, was noted, whilst about 200 yards further to the east a pebble-bed dipped in the opposite direction. Walking

* The same geologist to whom Professor A. H. Green has dedicated his admirable work on geology. 
along the beds in descending order, the volcanic character of the agglomerates was well shown in a pile of rocks near Old John, where angular pieces of slate, several feet long, were seen imbedded in an ashy matrix. The position of these agglomerates and their importance in the Charnwood Series and the direction of their outcrop were carefully considered. The Stable Quarry and other points of geological interest in the Park were all examined. On their way home the Members visited the Sheet Hedges Quarry, and took specimens of the syenite, which presents several interesting peculiarities. A full description of it will be found at page 270 of Mr. Teall's 'British Petrography.' The attention of the Members was called to the excellent sections of Upper Keuper in the cuttings of the quarry railway. The horizontal beds of Red Marl and Grey Sandstone, containing pseudomorphs of salt crystals, lying upon the uneven surface of the syenite, afforded a striking evidence of the quiet deposition of these beds upon the floor of the Triassic sea.

The next day's Excursion commenced at Mount Sorrel, where a large quarry has been worked for many years in the mass of hornblendic granite, which occupies at the surface an area of one or two square miles on the eastern margin of the Forest. It was pointed out that Charnwood presented in miniature all the features of a mountain chain. Its points of elevation are near and parallel to the anticlinal, and it is bounded on one side by one immense fault, and probably by another on the other side. The Rev. O. Fisher* has shown that in such chains the outbursts of igneous rock are not usually found along the anticlinal, but at some distance on either side, towards the roots of the hills, and this is well illustrated here by the positions of the great masses of igneous rock at Mount Sorrel and at Groby. The variety in the colour of the rock in different parts of the quarry was observed, and specimens of grey, salmon-colour, and red were easily obtained. The hornblende and the crystals of quartz and pinkish felspar were readily recognized by the naked eye, but the specks of black mica and magnetite were mostly too minute to be seen without a glass. Both felspars are a good deal decomposed. The hornblende has suffered in the same way, and the joints of the rock are filled with a * 'Trans. Camb. Phil. Suciety,' xii, Part ii, 1877.

Vol. X., No. 9 . 
bright yellowish-green epidote. Here and there are nodules of pyrites and sulphate of copper, with occasional traces of molybdenite. The black, sharply-defined patches which were seen on the fractured surfaces of the granite are probably included fragments of some other rock canght up in the granite whilst it was in a molten state.

The rock at Mount Sorrel, like several other masses on the Forest, marks a line of weakness, along which more than one extrusion has occurred at different times. A dyke of dolerite two or three yards wide runs through the quarry, and a few years since another of felstone could be seen, but this, the foreman said, had all been quarried away. The Members walked round by the northern end of the quarry to examine some peculiarities in the shape and surface of the rock which, it had been suggested, were the result of ice-action. Professor Blake said that he had examined this part of the quarry with the late Professor Carvell Lewis, and they both came to the conclusion that there was no evidence of the action of ice, and this was the general opinion of those present.

The route was then followed over the granite boss of Kinchley Hill to the onterops of diorite, which occur both outside and inside Brazil Wood. The Members spent a considerable time in the wood examining the contact which is visible here between the igneous and sedimentary rocks. Mr. Allport* first pointed out that the micaceous schist of the Brazil Wood is the slate of the Upper Forest bed altered by the intrusion of veins of granite. Approaching within a few yards of each other we have the mass of granite lying at the northern end of the wood, and at the other end a mass of ordinary sedimentary slate, and between these two comes a patch of contorted micaceous schist, in which may be seen the veins of the intruding granite which have caused the alteration of the slate into the schist. The contact is often sufficiently sharp for the granite and the schist to be well seen in a microscopic section. Half-an-hour's walk across the fields brought the Members to the deep quarries in the Workable Slates in Swithland Wood. They were quarried here years ago for roofing purposes, but were superseded by the thinner though softer Welsh slates. Some of these Swithland slates were not long since taken from

* 'Geol. Mag.,' Nov., 1879, 481. 
the roof of Rothley Temple, where they had been exposed to the weather for 600 years, and they were found to be as sharp as the day they were taken from the quarry. The Excursion concluded with an examination of the banded slates and pebblebeds of the hanging rocks in Beaumanor Park. After a careful inspection of the Ring Pit, the Members were of opinion that the circular workings seen there showed no evidence of organic origin. A few of the more active Members ascended Beacon Hill, and had a splendid view of the surrounding country.

The concluding Excursion, under the direction of the Rev. E. Hill, was devoted to the examination of the lower and mainly volcanic beds of the Charnwood Series. They are admirably shown in the section over which the Members worked, from the Forest Rock Inn to Blackbrook. The section shows the series in descending order, commencing with the porphyries, passing over the agglomerates, and finally reaching the lowest beds of all, the quartzites of Blackbrook and Ires Head. The thickness of these beds, with the addition of the Forest Gate Beds and the Workable Slates, according to Messrs. Hill and Bonney, is probably not less than 7,500 feet. The quarry close to the Forest Rock Inn showed the slate altered to a hornstone and dipping towards the south-west. Returning then to the road, the party proceeded first along the road leading to the Monastery and then along the fields parallel to it. Mr. Hill pointed out the cliffs composed of a thick bed of breccia with large included pieces of slate and other rocks embedded in an ashy matrix. Beyond were masses of agglomerates and coarse ash beds, and last of all were seen the banded grits or quartzites. The Members made their way back to the cross roads by the Monastery, High Sharpley, and Peldar Tor. The Sharpley rock possesses considerable interest, as a rock which Professor Bonney thinks closely resembles it has been found in a boring at a depth of 760 feet at Orton, near Kettering, 20 miles south of the Forest. During their stay in Leicester the Members did not confine their attention to the geology of the neighbourhood. Those who came down from town on Saturday afternoon spent a most agreeable two hours in the evening in looking over the Museum, which since the last visit of the Association has been so far remodelled by the Curator, Mr. Montague Browne, F.Z.S., as to take a very high rank amongst provincial museums. 
The artistic setting up of the animals in the vertebrate room was specially admired. The specimens of Saurians from the Lias at Barrow-on-Soar, in the geological room, of course received much attention from the Members. A cordial vote of thanks was given to the Curator for his kindness in conducting the Members round the Museum and for the trouble he had taken. The early hours of Monday, previous to the arrival of the Members who came down from town, were spent in examining the abundant Roman, Norman, and mediæval antiquities of Leicester.

\section{REFERENCES.}

Geological Survey Map, Sheet 63, N.E. and N.W.

Horizontal Sections 46, 48, and 52.

Hilt, Rev. F., and Bonney, Rev. T. G.- "The Pre-Carboniferous Rocks of Charnwood Forest," Quart. Journ. Geol. Soc., Vol. xxxiii, 1877, p. 754; xxxiv, 1878, p. 199; xxxvi, 1880, p. 337.

Bonney, Prof. T. G.-- "On the Archæan Rocks of Great Britain," Rep. Brit. Assoc., Montreal Meeting, 1884, p. 529 (Charnwood Forest, p. 536).

BerRY, E. E.-" Analyses of Five Rocks from the Charnwood Forest District," Quart. Journ. Geol. Soc., Vol. xxxviii, 1882, p. 197.

Harrison, J. W.- "A Sketch of the Geology of Leicestershire." (From White's Gazetteer.) Simpkin, Marshall \& Co., 1877. Large edition, with 12 photographs.

"Geology of the Counties of England." 1882 (Leicestershire, p. 151).

"On the Geology of Leicestershire," Proc. Geol. Assoc., Vol, v, 1877, p. 126.

—_. "Garnets in Charnwood Rocks." Midland Naturalist, vol. ii, p. 77. Allport, S., and Harrison, W. J.-"Rooks of Brazil Wood," Midland Naturalist, Vol. ii, p. 243.

Hudleston, W. H.- "Report of Excursion to Charnwood Forest," Proe. Geol. Assoc., Vol.iv, 1875, p. 307.

Notes on the Microscopic Character of some Specimens of Rocks collected during the Excursion to Charnwood Forest.

By Major-General C. A. McMahon, F.G.S.

On the occasion of the recent Excursion of the Geologists' Association to the Charnwood Forest under the guidance of Messrs. Hill and Paul, I secured some good specimens of the interesting rocks pointed out to us, and subsequently studied thin slices of them under the microscope for my own amuse- 